\title{
京町家の耐震性能評価と耐震補強設計法 \\ SEISMIC PERFORMANCE EVALUATION AND REINFORCEMENT DESIGN METHOD FOR EXISTING URBAN TRADITIONAL WOODEN HOUSES
}

\author{
須田＼cjkstart達*，鈴木祥 之**，奥田 辰 雄***，小笠原 昌敏* \\ Tatsuru SUDA, Yoshiyuki SUZUKI, Tatsuo OKUDA \\ and Masatoshi OGASAWARA
}

\begin{abstract}
To improve the seismic performance of existing urban traditional wooden houses, the seismic reinforcement design method is explored. From the structural observation of thirty traditional wooden houses so-called Kyo-machiya, their seismic performances were evaluated based on the response-limit capacity analysis. The result indicates that many Kyo-machiyas need the seismic reinforcement. Their seismic performances and seismic reinforcements are examined statistically. As an example, the seismic reinforcement design method for one typical Kyo-machiya is shown in detail. It is found that the proposed design method can improve the seismic performance of Kyo-machiya both in horizontal and vertical views by arranging appropriately seismic elements.
\end{abstract}

Keywords: Traditional wooden house, Seismic reinforcement, Response-limit capacity analysis, Seismic performance, Base shear coefficient, Maximum response deformation angle 伝統木造住宅, 耐震補強, 限界耐力計算, 耐震性能, ベースシア係数, 最大応答変形角

1.はじめに

京都は 1200 年の歷史都市として、我が国における芸術・文化の創 造や継承に大きな役割を果たしてきた。この歴史のなかで京都の木 造住宅は質の高い都市型の住空間を創造し、京町家として継承され ている。京町家は京都市の中心部に高密に分布し、平成 10 年に京都 市が行なった外観調查 ${ }^{1}$ から総戸数は約 28,000 戸とされ、他都市に 類を見ない特色ある町並み景観を形成している。しかし、平成 15 年 の同調査 ${ }^{2)}$ においては、京町家の総戸数は約 24,000 戸となり、著し く減少していることが判った。これら京町家の多くは戦前に建設さ れており、昭和 25 年に制定された建築基準法に適合していない既存 不適格建物である。これまで京町家は、建築意匠、地域生活などに 関する調査は数多く行なわれているが、構造に着目した調査はほと んど行われていない。そのため構造についてはこれまで、ほとんど 明らかにされておらず、大地震に対する安全性が不明であることが、 減少する要因の一つとして举げられる。さらに近年では、各地で大 地震が多発し、木造建物の被害が多く報告されている(3)4)5)。大地震 に対する住民の危機意識が高まりつつあるなかで、京都市では平成 15 年に第 3 次地震被害想定 ${ }^{6}$ を作成し、近隣を含めた 9 つの断層が 起因となってもたらす京都市域の地震被害についての想定が行われ、 甚大な被害を被る予測もされており、早急な対策が必要である。そ

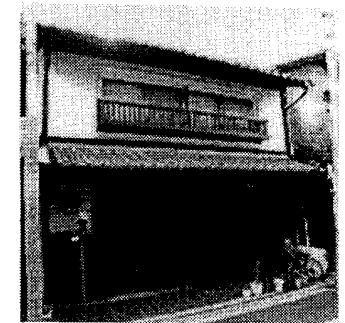

間口 3 間， 2 陼建て

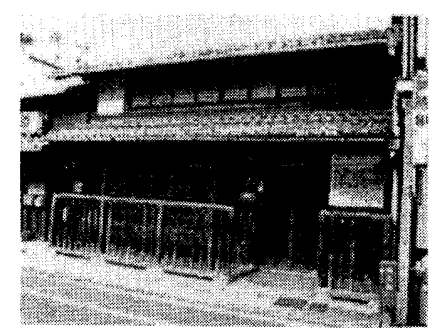

間口 3.5 間, 中 2 階建て

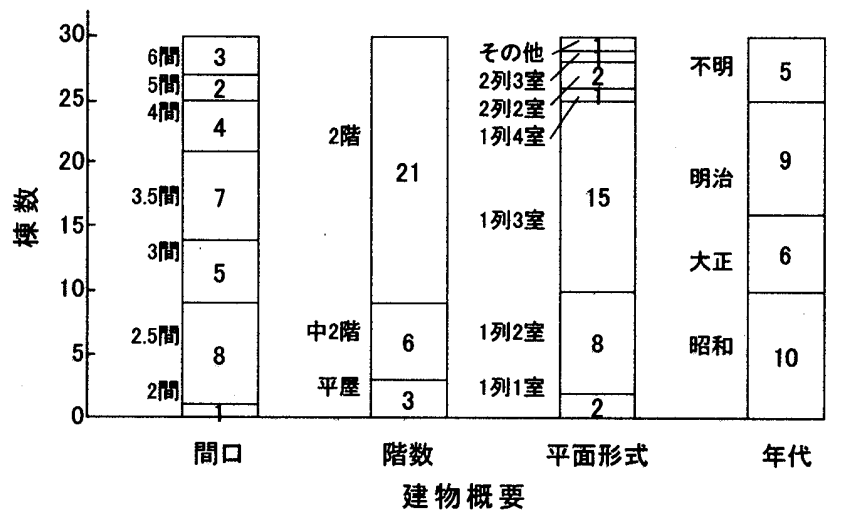

図 1 調查対象建物の概要構成

\footnotetext{
* 京都大学大学院工学研究科 大学院生.工修

** 京都大学防災研究所 教授・工博

*** 木四郎建築設計室 主莘
}

Graduate Student, Graduate School of Engineering, Kyoto University, M. Eng. Prof., Disaster Prevention Research Institute, Kyoto University, Dr. Eng. President, Kishiro Architecture and Design 
こで本報では、2003 年に京町家 30 棟を対象として構造的な雉点か ら詳細調查を行った結果7に基づいて、京町家の耐辳性能の評価を 行うと共に統計的な分析から、限界耐力計算 ${ }^{899}$ に上る耐震補強設計 の方針を提案し、現実的な耐震化への方向性を示す。

\section{2. 対象建物}

構造詳細調查の対象建物は、間口寸法と階数をパラメータとし、さ らに平面形態、立面形態が京町家の特徴を有すること、増改築が少 なく建設当時の状態が推測できることを条件として 30 棟を選出し た。選出の結果、間口寸法は 2 間から 6 間、階数は平屋、中 2 階、2 階建て、平面形態 ${ }^{10)}$ は 1 列 1 室から 1 列 4 室と 2 列 2 室、 2 列 3 室、 建筑年代は明治期から昭和初期であった。写真 1 は中 2 階と 2 階建 ての対象建物の外観を示し、図 1 はグラフ左側に項目、グラフ中に 棟数を表記した建物概要における対象建物の構成を示す。また図 $2 、$ 3 に京町家の平面形態と標準的な張り間方向およびけた行方向の主 要構面の軸組図を示す。

\section{3. 京町家の酎震要素}

構造詳細調查から、京町家の耐震要素は軸組と土塗り壁 (以下、土 壁)、土塗り小壁 (以下、小壁)であることがわかった。

3. 1 軸組 ${ }^{1112)}$

居室の柱は、100 mm角から $120 \mathrm{~mm}$ 角程度であり、柱脚部は礎石建 ちとし、柱頭部は短ほぞによって梁と接合する。側壁(かわかべ) 通

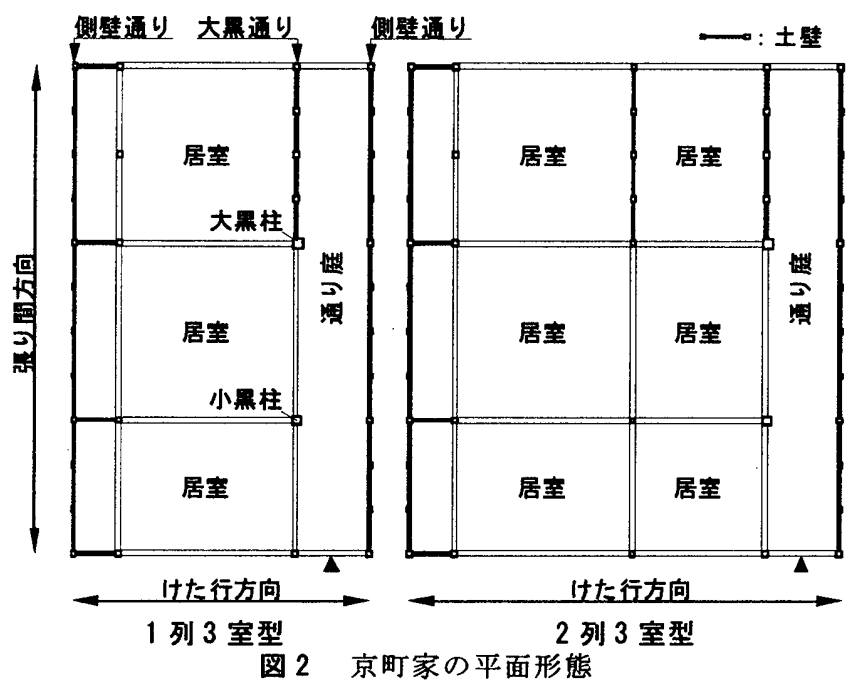

りの側柱は、半間間隔で設け、在来構法の胴差しに相当する横架材 はなく喏石から母屋まで通して、母屋に長ほぞを差して込み栓で留 める。側柱は角柱と半柱とが混在しており、角柱は $100 \mathrm{~mm}$ 角から $140 \mathrm{~mm}$ 角、半柱は見付けが $100 \mathrm{~mm}$ から $140 \mathrm{~mm}$ で奥行きが $60 \mathrm{~mm}$ から $100 \mathrm{~mm}$ 程度である。側柱間は断面 $12 \mathrm{~mm} \times 105 \mathrm{~mm}$ 程度の貫で慗がれ、 角柱には通し貫、半柱には柱の外側面を切り欠いて面を合せる程度 である。耐䅶要素となる横架材としては、玄関と 2 階桁の間に断面 の大きな人見梁がある。断面は $100 \mathrm{~mm} \times 150 \mathrm{~mm}$ から $120 \mathrm{~mm} \times 450 \mathrm{~mm}$ 程度と様々であるが、柱には長ほぞを差し込んで込み栓で留める。 水平構面は十分な水平剛性を有しているとは言い難く、各構面の 仕様は以下の通りである。2 階の床組は胴差しが無く、ササラのほ ぞを側柱に差し込んで込み栓で留める。床板は厚さ $12 \mathrm{~mm}$ から $15 \mathrm{~mm}$ 程度の杉板をササラに釘で留める。2 階の床も兼ねる大和天井は、 $30 \mathrm{~mm}$ 程度の厚さの杉板を用いる。1 階の床組は、主要な構面の柱間 に足固めがあり、等間隔に大引きを配置する。足固めには断面が 100 mmから $120 \mathrm{~mm}$ 角材または丸太を用いる。柱には短ほぞを差し込む 程度で、引き抜き方向に対して拘束する効果はほとんど無い。大引 きは、足固めに架ける場合と、足固めに架けず束で支えて独立して いる場合がある。小屋組の軸組は、地棟、登り梁、母屋、小屋束で 構成される。地棟は建物の奥行に応じて 1 本から 3 本、登り梁は建 物の間口に応じて 1 本から 2 本が架けられ、登り梁に小屋束を嘈き、 側柱と小屋束で母屋を支持する。ほとんどの対象建物において、小 屋束は貫で繫がれていない。

3.2 土壁 ${ }^{11) 12)}$

土壁は、胴差しを設けない側壁には 7 段程度の貫、間仕切り壁や 側壁以外の外壁には 3 段の貫を設けて、竹小舞下地に荒壁を塗り返 して中塗りし、仕上げる。外壁の仕上げは、中塗り止めもしくは漆 喰とし、間仕切り壁の仕上げは中塗り止め、大津壁、聚楽など部屋 の用途によって使い分けている。建物が隣接する側壁は、土壁を仕 上げた状態で側壁ごと設置する場合もあるが、調查対象建物のほと んどは、内側からのみ壁土を付けて仕上げている。貫の断面寸法は $12 \mathrm{~mm} \times 100 \mathrm{~mm}$ から $120 \mathrm{~mm}$ 程度、土壁の壁厚は $55 \mathrm{~mm}$ 程度である。な お多くの調査対象建物で、2 階の天井から上の部分や 1 階の床から下 の部分に荒壁が塗られていないことを確認した。写真 2 に天井上、 床下部分の土壁の状況を示す。

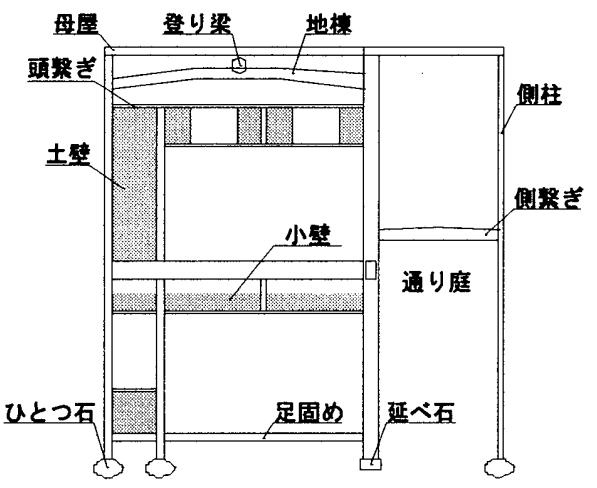

けた行方向

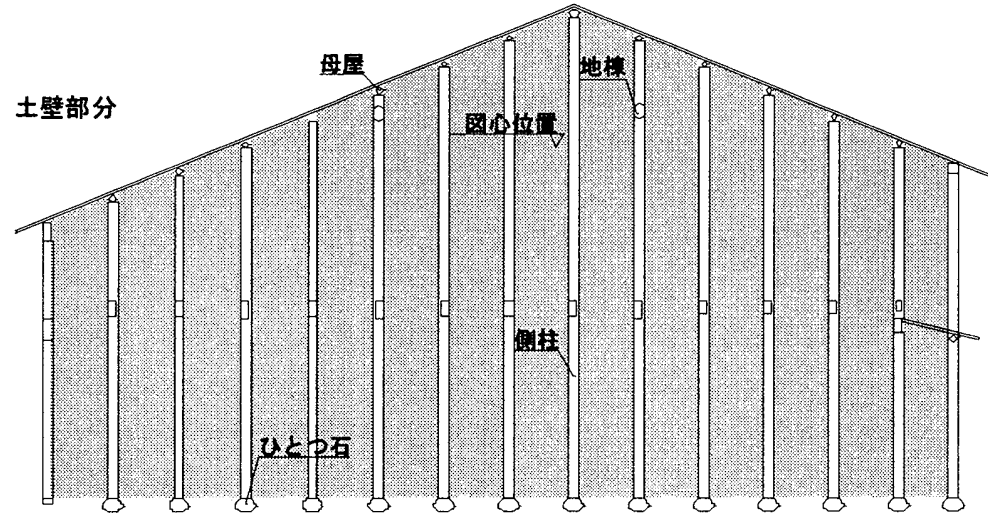

張り間方向

図 3 京町家の軸組図（中 2 階建て） 


\section{3 小壁}

小壁は、土壁と同様に、竹小舞下地に中叙り、仕上げの順に塗り、 壁厚は $55 \mathrm{~mm}$ 程度である。また 2 階天井から上部と 1 階床から下部に は荒壁が塗られていない。貫は小壁の壁高さに応じて、1 段から 2 段 に設けている。

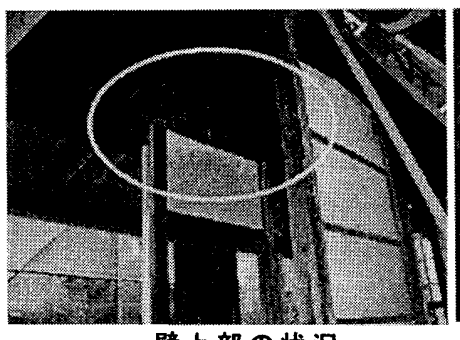

壁上部の状況
写嘪 2 土壁の状況

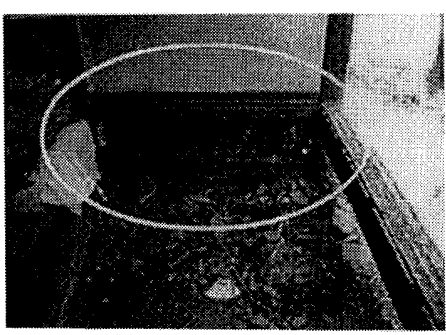

壁下部の状況

\section{4. 建物規模}

\section{1 建物重量}

建物重量は、表 1 に示す単位重量に基づいて算出した。単位重量 は、建築基滩法施行令第 84 条、85 条に基づいて設定しているが、屋 根構面、壁構面に関しては、建物重量に対して占める割合が大きい こと、地域によって様々な仕様があることから実測に基づいて単位 重量を設定している。京町家の屋根仕様は、莫き土を全面に真かず 筋葛きにして瓦を幕き、使用する瓦は現在の一般的な瓦と比べて厚 みが薄い。そこで解体中の京町家から瓦、莫き土を一部分取り出し て実測して単位重量を設定した。土壁は既往の研究 ${ }^{13) 14) に お い て 、 ~}$ 3.2 項で示した京都の仕様で製作された土壁試験体を実測して単位 重量を設定した。それぞれ設定した単位重量は実在する京町家の精 密な重量計測の結果 ${ }^{15)}$ と比較して適正な範囲であると言える。調査 対象建物の算出結果を延べ床面積との相関で図 4 に示す。同図中に 回帰曲線と相関係数 $(R)$ を示している。対象建物の地震時設計用建物 重量は、 $52 \mathrm{kN}$ から $639 \mathrm{kN}$ となり、延べ床面積で基準化すると $1.95 \mathrm{kN} / \mathrm{m}^{2}$ から $3.51 \mathrm{kN} / \mathrm{m}^{2}$ である。

\section{2 建物高さ}

建物高さは、最高高さを基礎から棟まで、2 階高さを 2 階床から 桁まで、1 階高さを基礎から 2 階床までとして実測した。ここで桁の 高さは、図 3 に示すように前後の高さが異なる場合があるため、そ れぞれ計測している。調查対象建物の実測の結果、最高高さは、1

表 1 単位重量と積載荷重 $\left(\mathrm{N} / \mathrm{m}^{2}\right)$

\begin{tabular}{|c|c|c|c|}
\hline 構面 & 項目 & 単位部材荷重 & 単位荷重 \\
\hline \multirow{3}{*}{ 幄根 } & 瓦革き（筋蕒き土含む） & 640 & \multirow{3}{*}{1040} \\
\hline & 母屋、小屋組 & 300 & \\
\hline & 天井 & 100 & \\
\hline \multirow{2}{*}{ 下屋 } & 瓦烡き(筋芫き土含む) & 640 & 640 \\
\hline & 鉄板蓝き & 200 & 200 \\
\hline \multirow{2}{*}{ 壁 } & 土壁 & 830 & \multirow{2}{*}{890} \\
\hline & 仕上げ材 & 60 & \\
\hline \multirow{6}{*}{ 床 } & 量敷 & 340 & \multirow{3}{*}{590} \\
\hline & 床ばり & 150 & \\
\hline & 天井 & 100 & \\
\hline & 板張 & 150 & \multirow{3}{*}{400} \\
\hline & 床ばり & 150 & \\
\hline & 天井 & 100 & \\
\hline \multicolumn{3}{|c|}{ 積戴荷重(地晨時) } & 600 \\
\hline
\end{tabular}

階建てで $3510 \mathrm{~mm}$ から $3936 \mathrm{~mm}$ 、中 2 階建て以上で $5740 \mathrm{~mm}$ から 8997 mmであり、2 階高さは、 $1179 \mathrm{~mm}$ から $3095 \mathrm{~mm} 、 1$ 階高さは $2538 \mathrm{~mm}$ か ら $3380 \mathrm{~mm}$ の範囲であった。表 2 に建物の階数別に平均值と標準偏差 を示す。また以降に建物全体を質点系にモデル化して応答計算を 行っており、その際の 2 階高さは、2 階析上部の妻壁部分の図心位置 を 2 階の高さ (図 3 参照) とした。図 5 に応答計算でモデル化した際 の 1 階高さに対する 2 階高さの比を示し、図中に平均值と標淮偏差 を示す。

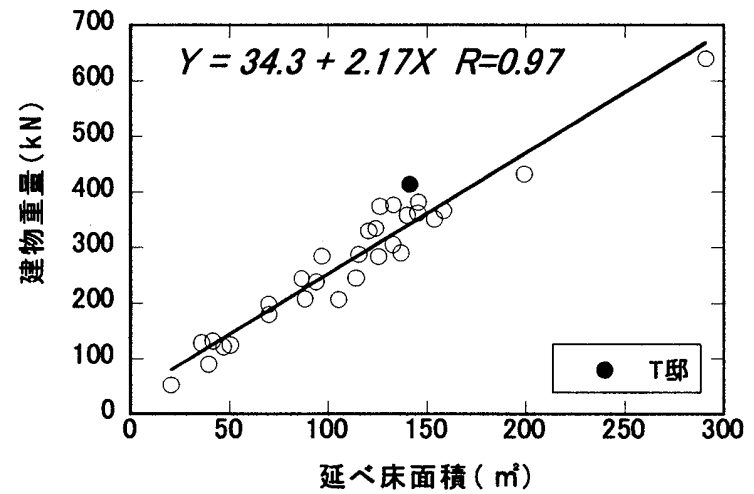

図 4 延べ床面積と建物重量の関倸

表 2 建物高さの平均値と標準偏差 $(\mathrm{m} \mathrm{m})$

\begin{tabular}{|c|r|r|c|}
\hline & \multicolumn{1}{|c|}{ 平屋 } & 中2階 & 2階 \\
\hline 最高高さ & $3747(217)$ & $6664(611)$ & $7331(721)$ \\
\hline 2阵高さ(高い側) & - & $2181(254)$ & $2559(234)$ \\
\hline 2階高さ(低い側) & - & $1381(221)$ & $2468(266)$ \\
\hline 1階高さ & $2614(67)$ & $2850(197)$ & $3010(210)$ \\
\hline
\end{tabular}

()内の数值は標準偏差

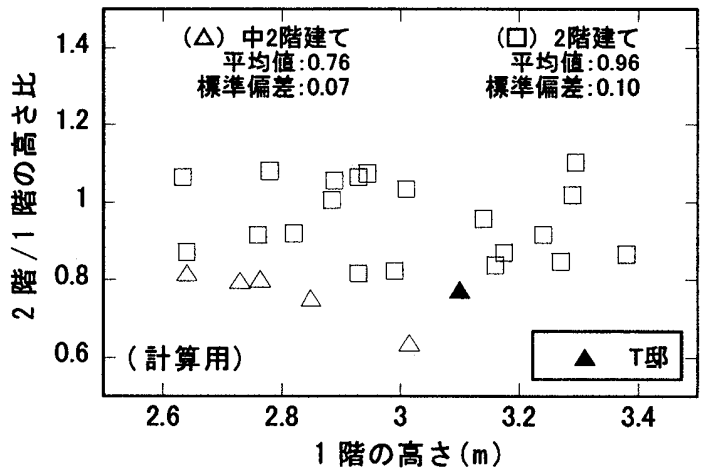

図 5 1 階の高さに対する 2 階の高さの比

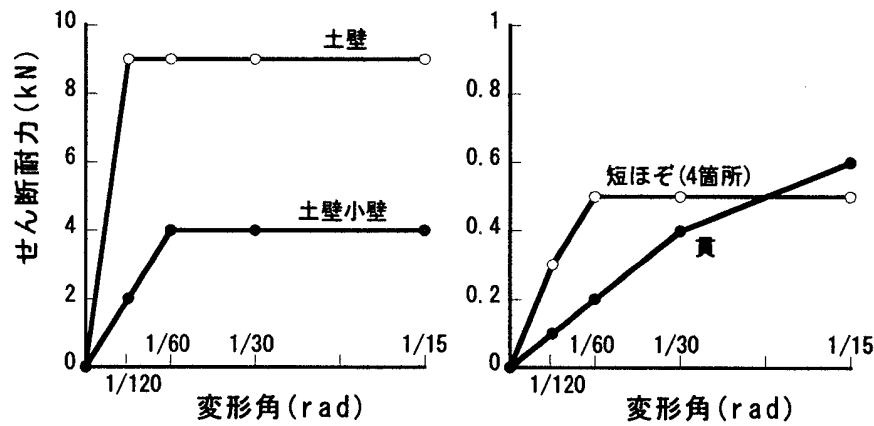

図 6 耐震要素の復元力特性 

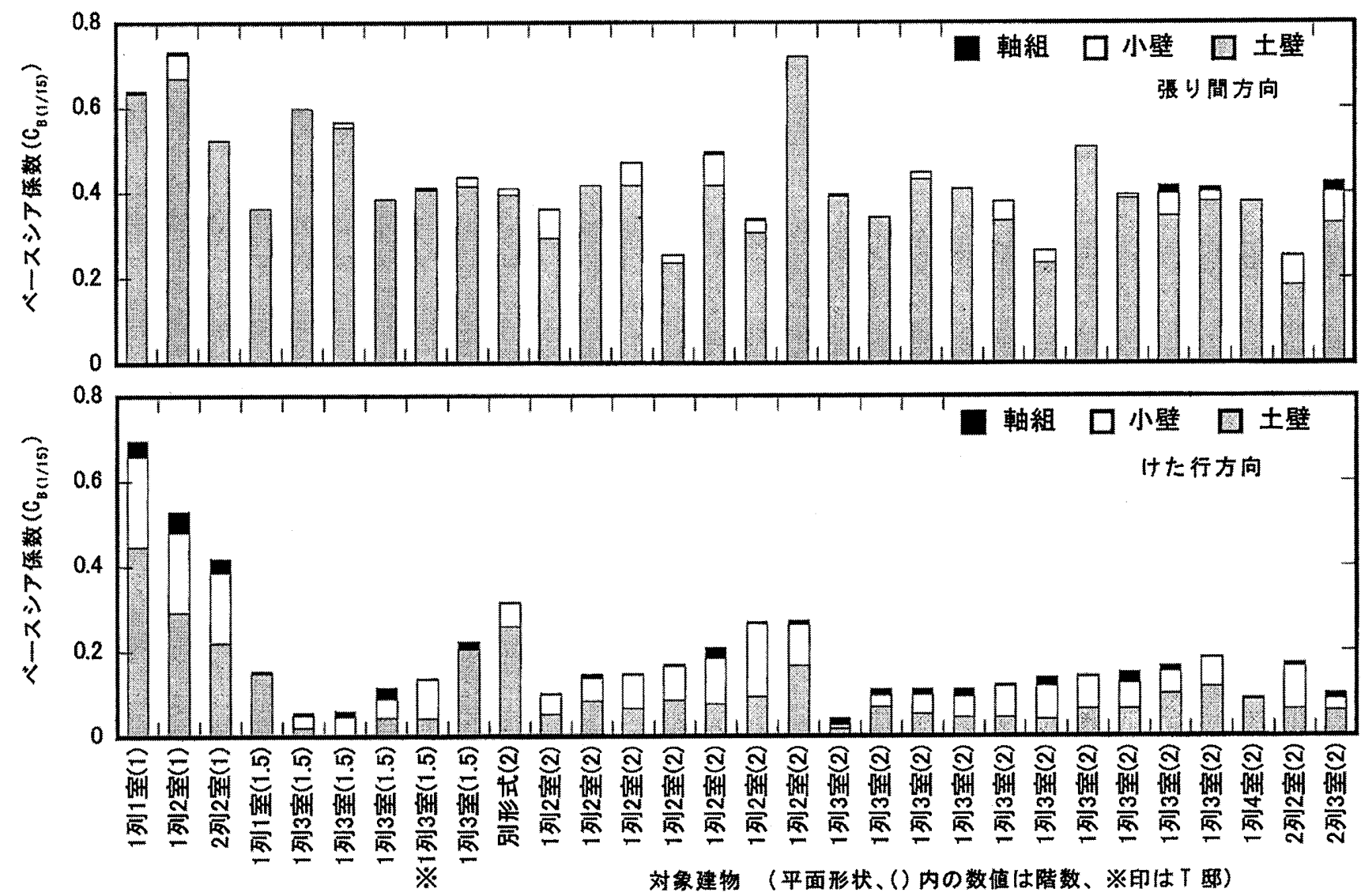

図 7 耐力要素の構成

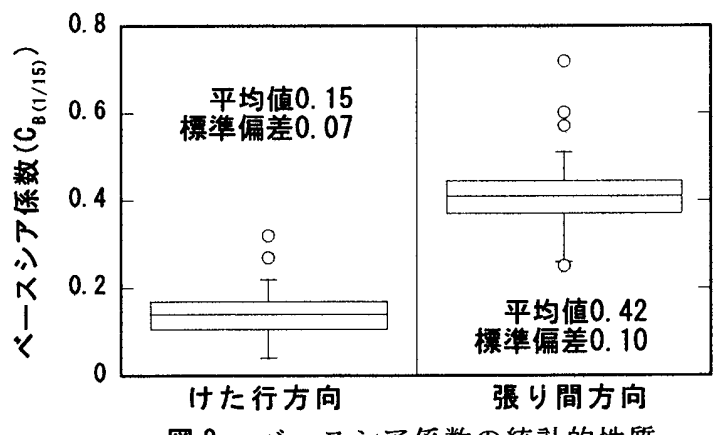

図 8 ベースシア係数の統計的性質

\section{5. 耐震性能}

対象建物 30 棟の構造詳細調查から耐震要素を明らかにし、各要素 の復元力を加算して建物の復元力を算出した。各要素の復元力は、 既往の文献 ${ }^{813)}{ }^{1314}$ に基づいて、基準となる復元力 (以下、基淮值）から 対象とする要素の仕様に态じて換算して算出する。図 6 に京町家の 耐震要素の基準となる復元力特性を示す。換算方法として、土壁は 基準値に対して壁長さに比例して算出する。土壁上下の隙間は、隙 間が大きくなるにつれて小壁に近づくと仮定して、架構の高さに対 する壁土の高さの比を求めて、小壁の耐力と線形補間を行って低減 している。小壁は柱間に取り付く小壁を 1 枚として、基準值に対し て枚数に比例して算出する。小壁の基準値も土壁と同様に小壁の高 さに応じて低減している。軸組は柱端部のほぞ接合部によるせん断 耐力であり、基準値に対して接合部のめり込み面積に比例し、架構 の高さに反比例して算出している。

京町家の耐震性は耐力特性に加えて変形性能も重要な性能となる
ため、図 7 に耐力要素の構成を変形角 $1 / 15 \mathrm{rad}$ 時のせん断耐力によ るベースシア係数 $\left(\mathrm{C}_{\mathrm{B}(1 / 15)}\right)$ で示す。同図の横軸は、各建物の平面形状 を示しており、()内の数値は 1 階建てを 1 、中 2 階建てを $1.5 、 2$ 階 建てを 2 として示し、階数が低く、部屋数が少なく、さらにけた行 方向のせん断耐力が小さい順に並んでいる。また、評価の基準を間 ロおよび高さによる規模と平面形態で統一するために経年的な劣化 は考虑しない。増改勧箇所は、所有者へのヒヤリングや調査員の経 験的知識に基づいて、建築当初を想定して排除している。

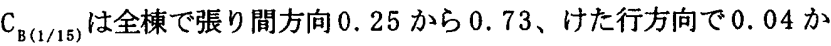
ら 0.7 である。平屋建ての 3 棟は規模が小さく、建物方向によらず $\mathrm{C}_{\mathrm{B}}$ $(1 / 15)$ は比較的高い。中 2 階以上の $\mathrm{C}_{\mathrm{B}(1 / 15)}$ を統計的に図 8 の箱ひげ図で 示す。張り間方向の平均値と標準偏差はそれぞれ 0.42 と0.1、けた 行方向は 0.15 と 0.07 である。張り間方向の $\mathrm{C}_{\mathrm{B}(1 / 15)}$ は建物規模によ る影響は少ないが、けた行方向の $\mathrm{C}_{\mathrm{B}(1 / 15)}$ は建物規模が大きくなるほど 小さくなる傾向がある。特に京町家の標準規模である 2 階建ての 1 列 3 室以上では $\mathrm{C}_{\mathrm{B}(1 / 15)}$ が 0.2 を超える建物はなく、張り間方向とは平 均值で 2 倍を超える差がある。耐力の構成について、張り間方向は、 土壁が約 8 割以上を占める。けた行方向は小壁の占める割合が大き くなり、土壁とそれ以外の割合が平均的にほぼ等しい。

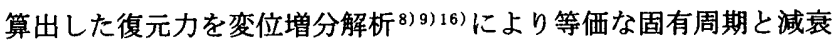
特性をもつ 1 自由度系に置換し、限界耐力計算 ${ }^{899}$ に基づいて最大応 答変形角を算出して耐震性能評価を行った。図 9 に算出結果を示す。 ここで地震力は安全限界に対応する極めて希に発生する地震動とし て、建築基隻法施行令第 82 条の 6 の加速度応答スペクトルを用いて 算定し、地盤種別は第 2 種地盤とした。 


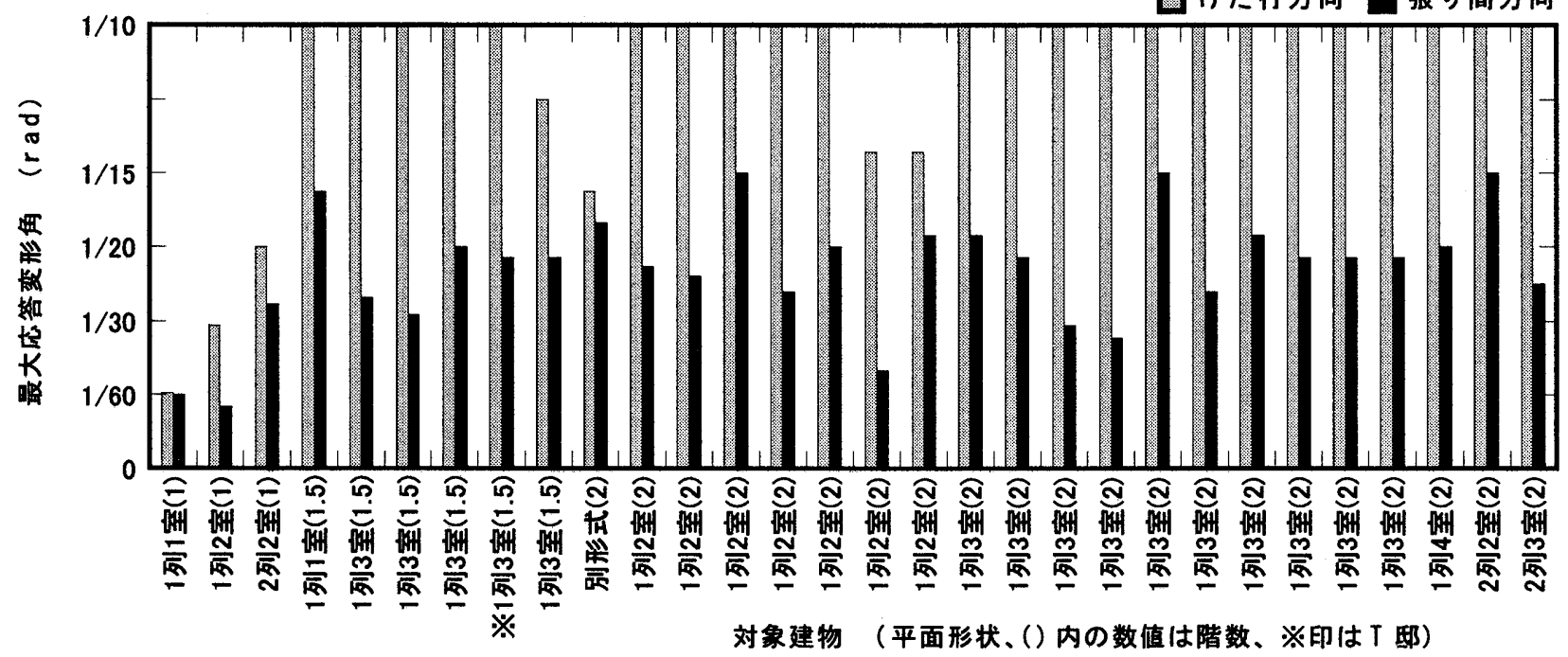

図 9 限界耐力計算による最大応答変形角 (第 2 種地盤)

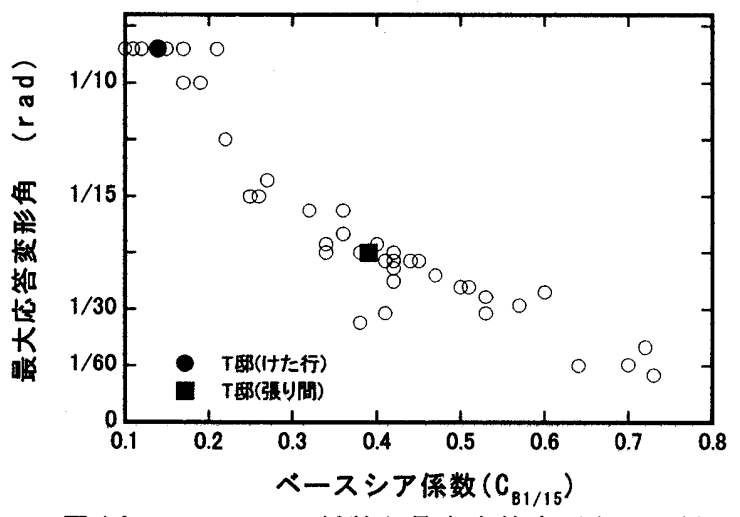

図 10 ベースシア係数と最大応答変形角の関係

張り間方向の最大応答変形角は、いずれも安全限界変形角とされ

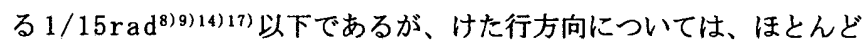
の建物が安全限界変形角を大きく超えており、耐祳性能は極めて低 い。また、けた行と張り間方向の算出結果を併せて、 $C_{B(1 / 15)}$ と最大応 答変形角の関係を図 10 に示す。同図から $\mathrm{C}_{\mathrm{B}(1 / 1) \mathrm{l}}$ が約 0.25 付近から以 降で安全限界変形角以下になっている。

\section{6. 耐震補強方法}

耐震補強の方法としては、建物重量の軽減、耐力の向上、减衰力 の向上などがある。屋根瓦の草き替えによる重量の軽減は、4 章で 示すとおり、現在の一般的な瓦と比べて大差なく大幅な軽減になら ない15)。限界耐力計算の結果では、平屋建てを除く対象建物 27 棟 は、ほとんどの場合が 2 層に比べて 1 層の変形が大きくなる。また 張り閒方向に比べてけた行方向の耐力が極めて低いことから、1 層 の耐力を向上させる必要がある。そこで典型的な京町家 T 邸の耐震 補強設計例を示す。図 11 に構造平面図、図 12 にけた行方向各層の 復元力特性、表 3 に建物諸元を示す。図 13 は耐震性能評価の結果を 示し、地盤種別ごとの地震力から求まる必要性能スペクトルと 1 自 由度系の復元力の交点を応答值として図中に○で示す。T 邸のけた 行方向の耐震性能は $\mathrm{C}_{\mathrm{B}(1 / 15)}$ が 0.14 と低いため、地震力を第 2 種地盤 とした場合に応答値は求まらない。第 1 種地盤の場合では応答値が 求まり、これを各層に分配 ${ }^{8)} し て 2$ 層の応答変形角は $1 / 156 \mathrm{rad} 、 1$
層の忘答変形角は $1 / 15 \mathrm{rad}$ である。また京町家の水平構面は 3.1 節 に示すとおり、䍑床とは言い難いので、主要構面ごとに耐震性能評 価を行った結果を図 14 に示し、ここでは第 1 種地盤による地震力と している。荷重等負担面積は主要構面間で等分している。図中の凡例 は主要構面を示し、図中() 内に最大忘答変形角を示す。図 14 から、 $\mathrm{X} 1$ 構面から X4 構面にかけて徐々に耐震性能が低くなることがわかり、 X4 構面を主に耐震補強する必要があると判断できる。

次に、平面的な構造要素のバランスに加えて、立面的なバランス を整えることで耐震性の向上を図る。T 邸の耐震性能評価から、2 層 はほとんど変形せず、1 層が大きく変形していることが分かってい

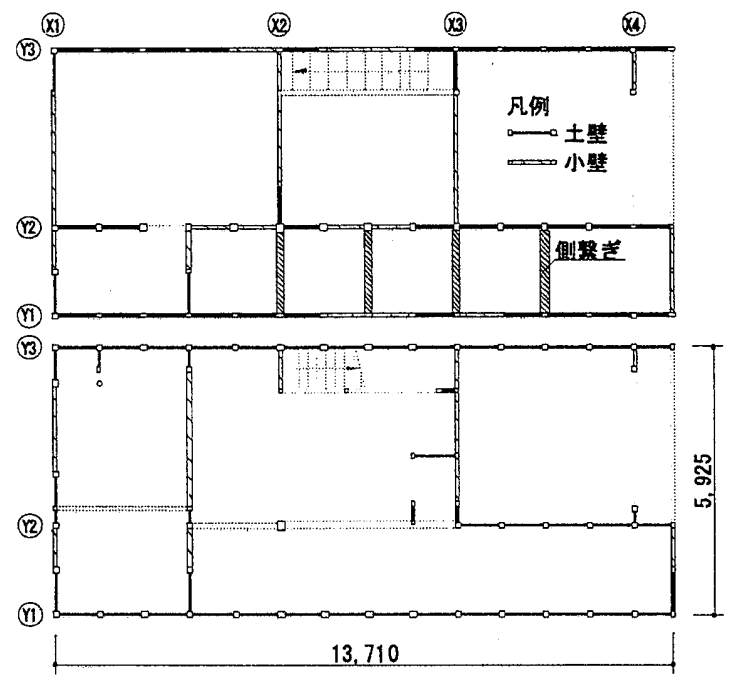

図 $11 \mathrm{~T}$ 邸の構造平面図 (上: 2 階、下: 1 階) 表 $3 \mathrm{~T}$ 邸の建物諸元

\begin{tabular}{|c|c|c|}
\hline \multirow{2}{*}{$\begin{array}{c}\text { 建物重且(尌算用) } \\
(\mathrm{kN})\end{array}$} & 2層 & 200 \\
\hline & 1層 & 213 \\
\hline \multirow{2}{*}{$\begin{array}{c}\text { 建物高さ(㖕算用) } \\
(\mathrm{m}) \\
\end{array}$} & 2層 & 2.4 \\
\hline & 1層 & 3.1 \\
\hline \multirow{2}{*}{$\begin{array}{c}\text { 休面稳 } \\
\left(\mathrm{m}^{2}\right)\end{array}$} & 2階 & 60.2 \\
\hline & 1階 & 81.2 \\
\hline \multirow{2}{*}{$\mathrm{C}_{\mathrm{B}(1 / 15)}$} & $1 t t=$ 行 & 0.14 \\
\hline & 張り間 & 0.39 \\
\hline
\end{tabular}




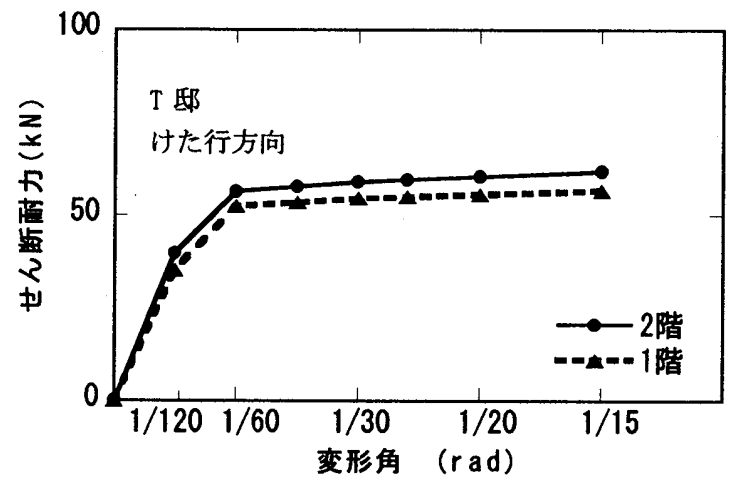

図 $12 \mathrm{~T}$ 邸の復元力

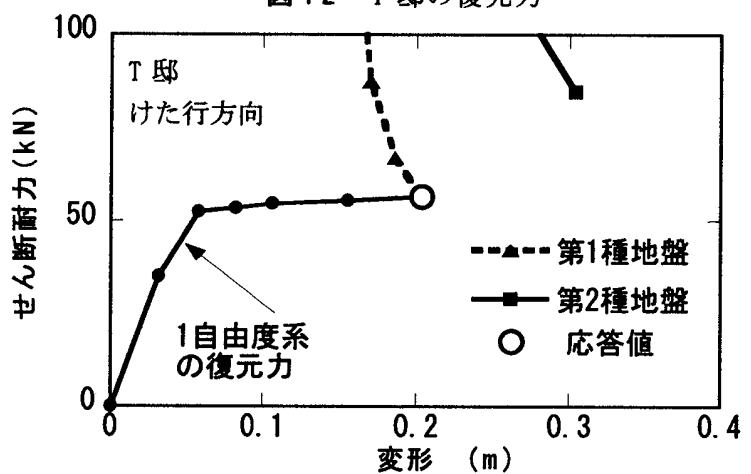

图 $13 \mathrm{~T}$ 邸の耐震性能評価

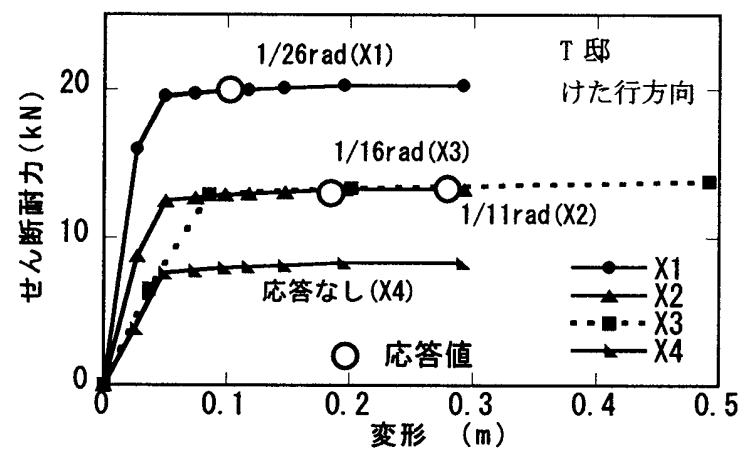

図 14 主要構面の耐震性能評価

るので、1 層の耐震補強を想定する。図 15 に、せん断耐力を徐々に

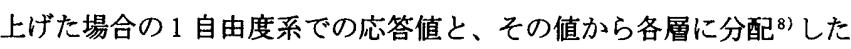
応答変形角を示す。その際の補強要素は、図 6 に示した土壁や小壁 を想定している。図 15 において横軸が 0 のときは、補強なしの状態 を示す。補強量が增加するに従って各層の応答変形角が徐々に近づ いて一致するが、さらに補強量を増加させると 2 層の応答が大きく なることが分かる。このように、各層の応答変形角が一致するよう な補強効果となる適正な耐力補強量が存在する。そこで、各層の応 答変形角をバランス良く一致させるために、最適な剛性比 (1 層の剛 性に対する 2 層の剛性）を求め、必要な補強量を決定する。図 16 に 示すように各層の応答変形角が等しい固有モードになるように、1 層の剛性を式(1)、(2)により算出し、必要な 1 層の補強量を求めた。 なお、ここでは各層の剛性は降伏点となる変形角 $1 / 120 \mathrm{rad}$ 時の剛 性を対象にしている。またこの計算過程において、剛性比が大きい 場合には、想定する固有モードとするには、式(1)、(2)を繰り返し て収束させる必要がある。算出した補強量を付加して耐震性能評価 を行った結果を図 17 に示す。第 1 種地盤とした場合の応答変形角 は、2 層で $1 / 34 \mathrm{rad} 、 1$ 層で $1 / 29 \mathrm{rad}$ 、同様に第 2 種地盤とした場合

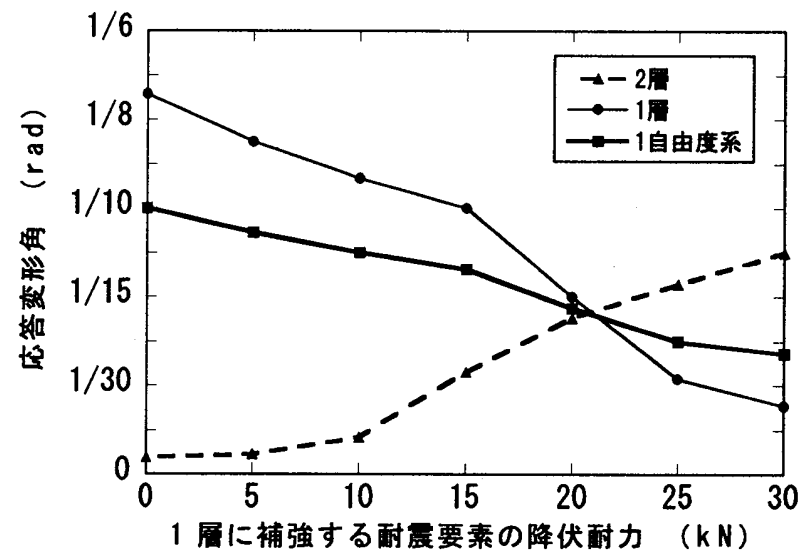

図 15 補強量に伴う応答変形角の推移

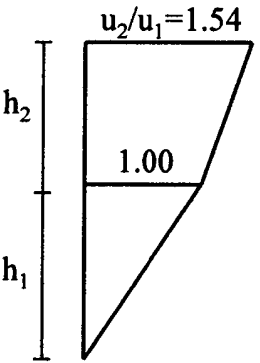

「 邸の固有モード

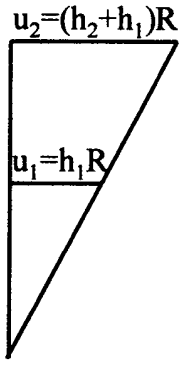

想定する固有モード

$\mathrm{u}_{2}: 2$ 層の変位量

$\mathrm{u}_{1}: 1$ 層の変位量

$\mathrm{h}_{2}: 2$ 層の高さ

$\mathrm{h}_{1}: 1$ 層の高さ

$R:$ 変形角
図16 固有モード図

$$
\begin{aligned}
& \left|-\omega^{2} M+K\right|=0 \\
& \frac{u_{2}}{u_{1}}=\frac{-k_{11}+m_{1} \omega^{2}}{k_{12}}
\end{aligned}
$$

$[K]=\left[\begin{array}{ll}k_{11} & k_{12} \\ k_{21} & k_{22}\end{array}\right],[M]=\left[\begin{array}{cc}m_{1} & 0 \\ 0 & m_{2}\end{array}\right]$

$[K]:$ 㓮性マトリクス $[M]$ :質量マトリクス $\omega$ :固有円振動数

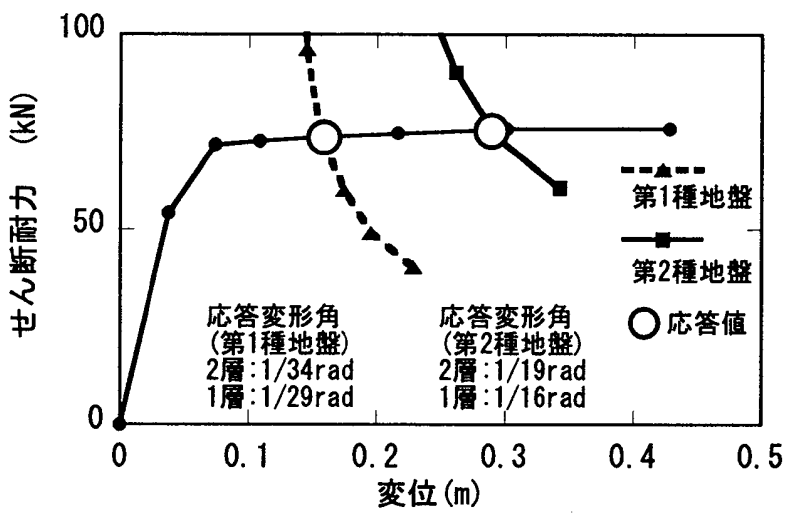

図 17 補強後の耐震性能評価（けた行方向）

では、 2 層で $1 / 19 \mathrm{rad} 、 1$ 層で $1 / 16 \mathrm{rad}$ となり、第 2 種地盤として も、設定した安全限界変形角を満足する。 $\mathrm{T}$ 邸の場合には、必要な 補強量を満足し、かつ平面的なバランスを考慮してX4 構面を主に各 構面に分配することによって、平面的、立面的にバランスの取れた 補強となる。 


\section{7. まとめ}

京町家 30 棟の構造詳細調查から、建物を構成する軸組や耐震要素 を明らかにした。限界耐力計算による耐震性能評価の結果では、け た行方向の耐展性が極めて低く、中 2 階、2 階建ての京町家のほとん どが倒壊の危険性があり、耐震補強の必要性を示した。また、30 棟 のベースシア係数と最大忘答変形角との統計的な分析から耐震補強 における耐力補強のおよその目安を示した。

耐震補強においては、詳細な構造調査に基づいて現状の建物の耐 震性能評価(耐震診断) を行い、対象建物に適した構造要素を用いて 補強を行う必要があり、京町家では耐力特性のみならず変形性能を 併せて検討する必要がある。

30 棟の中から標淮的な規模の中 2 階建て、1 列 3 室型の京町家を 例とした耐震補強設計を行い、各層の忘答変形角を一様にする設計 規範のもとに必要な耐力補強量を算出する方法を提案した。さらに 主要構面ごとに耐震性能を評価することで、平面的にも立面的にも バランスの良い合理的な耐震補強を行うことができることを示した。

本報における京町家を対象として得られた研究成果は、全国に現 存する町家など伝統木造住宅にも適用し得るものであり、伝統木造 住宅の耐震設計や耐震補強において有用な知見となり得ると考える。

\section{謝辞}

京町家 30 棟の調查は、京都市の助成を受け平成 15 年度に実施さ れた。調查には、地域住民の方々に快くご協力頂きました。京都府 建築工業協同組合、(社) 京都府建築士会木造建築研究会、NP0 法人京 町家再生研究会、京町家作事組、NP0 法人日本伝統建築技術保存会 および京都市建築指導課の方々には精力的に調查を実施して頂き、 京都建築構造研究会木造部会、（社）日本建築構造技術者協会関西支 部木構造分科会には耐震性能の評価でご協力を頂いた。ここに記し て感謝の意を表する。

\section{参考文献}

1）京都市：京町家まちづくり調査詳細集計結果, 1999.3

2) 京都市：京町家まちづくり調查詳細集計結果, 2004.3

3）阪神・淡路大屡災災害調查報告編集委員会：阪神・淡路大震災䛯查報 告, 建築編 -4 木造建築, 1998.3

4）北原昭男, 林康裕, 奥田辰雄, 鈴木祥之: 2000 年鳥取県西部地展における 木造建物の棈造特性と被害，日本建築学会粠造系論文集, No. 561, pp. 161$167,2002.11$

5）清水秀丸，林康裕，鈴木祥之，斎藤幸雄，後藤正美：2003 年 7 月 26 日 宮城県北部の地震による被災木造住宅の棬造的特徵と耐震性能, 日本建 築学会構造系論文集, No. 598, pp. 43-49, 2005.12

6）京都市：京都市第 3 次地震被害想定報告書，2003.10

7）須田達，鈴木样之，奥田辰雄，小笠原昌敏：京町家の楼造調查に基つく 粠造特性の評価、地域安全学会論文集 No. 7,pp. 15-21, 2005.11

8）木造軸組構法建物の䩂震設計マニュアル編集委員会：伝統構法を生か す木造耐震設計マニュアルー限界耐力計算による耐震設計・耐震補強 設計法一, 学芸出版社, 2004.3

9）鈴木祥之，斎藤幸雄，樫原健一，五十子幸㰾，野島千里：木造軸組の耐 震性能評価法一小変形から大変形・倒壊の領域まで評価する限界耐力 計算, 第 11 回日本地晨工学シンポジウム, pp. 1523-1528, 2002.11

10）京町家作事組編著：町家再生の技と知恵 京町家のしくみと改修のて びき，学芸出版社，2002.5

11) 武井豊治: 古建築辞典, 理工学社, 1994.5

12）住吉寅七，松井源吾:木造の継手と仕口，鹿岛出版会，1989.6

13）山田真澄, 鈴木祥之, 後藤正美, 清水秀丸：単位木造フレームを用いた 動的・静的実験による木造軸組の耐震性能評価, 日本建築学会樓造系論 文集，No. 582, pp. 95-102, 2002

14）鈴木祥之，清水秀丸，須田達，北原昭男：実大振動実験による軸組樓法 2 階建木造住宅の動特性と耐震性一筋かい付及び土壁付木造軸組の振動 台実験一, 2002 年日本地震工学シンポジウム, pp. 1377-1382, 2002. 11

15）鈴木祥之，下西智也，清水秀丸，須田達，小笠原昌敏，杉山克太：伝統 木造住宅の重量算定一京町家の実大震動台実験における重量計測一，日 本建築学会技術報告集第 24 号, 2006. 12

16）野島千里, 樫原健一，鈴木祥之：木造軸組の耐震性能評価法一変位增分 法一, 日本建築学会学術講演梗概集 C-1, pp. 397-398, 2002.8

17）鈴木祥之, 中治弘行 : 木造住宅土塗り壁の実大実験による耐裂性能の再 検郡，日本建築学会構造系論文集, No. 515,pp. 115-122, 1999.1 